\section{Fertilizer-nitrogen Management in an Onion and Tropical Pumpkin Rotation in Puerto Rico}

\author{
David Sotomayor-Ramírez ${ }^{1,3}$, Miguel Oliveras-Berrocales ${ }^{2}$, and \\ Linda Wessel-Beaver ${ }^{1}$
}

Additional index words. Allium cepa, Cucurbita moschata, residual soil N, crop response, soil fertility, nutrient management

\begin{abstract}
Summary. Onion (Allium cepa) and tropical pumpkin (Cucurbita moschata) combined contribute $13 \%$ of the total gross agricultural income (GAI) for vegetable crops in Puerto Rico, which is estimated at $\$ 54.5$ million. Both crops are usually rotated on an annual basis. In this study, an onion-tropical pumpkin rotation was used to test the effect of fertilizer-nitrogen $(\mathrm{N})$ on agronomic indicators of onion (plant height, number of leaves per plant, leaf color index, and leaf nutrient concentration), yield of both onion and tropical pumpkin, and inorganic $\mathrm{N}$ changes in the soil profile. Three fertilizer-N levels $\left(140,196,252 \mathrm{~kg} \cdot \mathrm{ha}^{-1}\right)$ were applied to onion, followed by 112 and $280 \mathrm{~kg} \cdot \mathrm{ha}^{-1}$ of $\mathrm{N}$ applied to tropical pumpkin. For tropical pumpkin, $\mathrm{N}$ was applied in plots with the lowest and highest fertilizer- $\mathrm{N}$ levels from the previous onion crop. Changes in onion agronomic indicators with increasing $\mathbf{N}$ fertilization were either not significant or showed no clear trend. There was no increase in total and marketable yields and number of onions with increasing fertilizer-N levels. Tropical pumpkin yields significantly increased with $280 \mathrm{~kg} \cdot \mathrm{ha}^{-1}$ compared with $112 \mathrm{~kg} \cdot \mathrm{ha}^{-1}$ of $\mathrm{N}$. Using $112 \mathrm{~kg} \cdot \mathrm{ha}^{-1}$ as a baseline fertilizer-N application, the value/cost ratio for tropical pumpkin was $\$ 12.70$ per dollar of fertilizer- $\mathbf{N}$. In low fertilizer- $\mathbf{N}$ plots, immediately available inorganic soil $\mathbf{N}$ (0 to $30 \mathrm{~cm}$ ) did not change between the onion and tropical pumpkin crop, but then decreased at the end of the rotation. In high fertilizer- $N$ plots, immediately available soil $\mathrm{N}$ greatly increased after onion, but then decreased at the end of the rotation. Potentially leachable soil $\mathrm{N}(30$ to $100 \mathrm{~cm})$ also increased after the onion crop and then decreased after pumpkin. However, in high fertilizer-N plots, potentially leachable soil $\mathrm{N}$ remained $44 \%$ higher at the end, compared with the beginning, of the rotation. The increased income attainable with the highest fertilizer- $\mathrm{N}$ in tropical pumpkin may be offset by greater residual soil $\mathrm{N}$ in the lower part of the soil profile, and the potential for this $\mathrm{N}$ to have a negative environmental impact.
\end{abstract}

I 2009-10, GAI for horticultural crops in Puerto Rico was estimated at $\$ 54.5$ million (Puerto Rico Department of Agriculture, 2011). Onion production was 93,169 cwt with a GAI of $\$ 1.55$ million, and tropical pumpkin production was 191,779 cwt with a GAI of $\$ 5.75$ million. Tropical pumpkin is a type of winter squash widely consumed in the humid tropics. Onion and tropical pumpkin combined contribute

This work was supported by the University of Puerto Rico, Agricultural Experiment Station. We recognize and appreciate the collaboration of graduate student Remy Rodríguez, and grower Carlos Gonzalez and his staff, especially agronomist Moises Soto.

${ }^{1}$ Department of Agro-environmental Sciences, College of Agricultural Sciences, University of Puerto Rico-Mayagüez Campus, P.O. Box 9000, Mayagüez 00681-9000, Puerto Rico

${ }^{2}$ Former graduate student, U.S. Department of AgricutureNatural Resources Conservation Service, Hope Field Service Center, Hope, AR 71802-0768

${ }^{3}$ Corresponding author. E-mail: david.sotomayor@ upr.edu.

doi: 10.21273/HORTTECH03482-16 about $13 \%$ of the total vegetable crop GAI in Puerto Rico. Although 95\% of the total tropical pumpkin consumption in Puerto Rico is produced locally, only $25 \%$ of the onion consumed locally is produced on the island. Onion is usually grown from November to March followed by tropical pumpkin during the spring and early summer in the southern coast of Puerto Rico. The fields usually remain fallow during the July to October rainy season.

Onion is a high-value crop with a shallow root system that is frequently irrigated and fertilized with medium to high nitrogen rates to maximize yield (Halvorson et al., 2002; Olson et al., 2011). In contrast, tropical pumpkin has a deeper root system that would be expected to take up residual soil $\mathrm{N}$. Thus, fertilizer rates for tropical pumpkin are usually lower, in the range of 50 to $75 \mathrm{lb} /$ acre of $\mathrm{N}$ in rotation, whereas rates for onion range from 125 to $175 \mathrm{lb} /$ acre of $\mathrm{N}$. Studies in onion production conducted in Mollisols in Puerto Rico showed no yield response when fertilizer-N varied from 56 to $336 \mathrm{~kg} \cdot \mathrm{ha}^{-1}$ of $\mathrm{N}$ (Alers-Alers et al., 1979) or from 75 to $336 \mathrm{~kg} \cdot \mathrm{ha}^{-1}$ of $\mathrm{N}$ (Colberg and Beale, 1991). Halvorson et al. (2008) reported yield and onion bulb size increased with fertilizer-N at $132 \mathrm{~kg} \cdot \mathrm{ha}^{-1}$ of $\mathrm{N}$, but this was not observed in the second year within the same plots. Ells et al. (1993) concluded that onion yields of $50 \mathrm{t} \cdot \mathrm{ha}^{-1}$ could be obtained without any $\mathrm{N}$ fertilizer when more than $42 \mathrm{mg} \cdot \mathrm{kg}^{-1}$ nitrate- $\mathrm{N}\left(\mathrm{NO}_{3}-\mathrm{N}\right)$ was initially present in the top $30 \mathrm{~cm}$ of soil. Shock et al. (2000) found consistent onion yield increases in 30 different cultivars in a 2-year evaluation in an Aridisol in eastern Oregon, using broadcast $\mathrm{N}$ rates from 22 to $50 \mathrm{~kg} \cdot \mathrm{ha}^{-1}$.

\begin{tabular}{llll}
\hline $\begin{array}{l}\text { Units } \\
\text { To convert U.S. to SI, } \\
\text { multiply by }\end{array}$ & U.S. unit & SI unit & $\begin{array}{l}\text { To convert SI to U.S., } \\
\text { multiply by }\end{array}$ \\
\hline 10 & $\%$ & $\mathrm{~g} \cdot \mathrm{kg}^{-1}$ & 0.1 \\
0.4047 & $\mathrm{acre}(\mathrm{s})$ & $\mathrm{ha}$ & 2.4711 \\
45.3592 & $\mathrm{cwt}$ & $\mathrm{kg}$ & 0.0220 \\
0.3048 & $\mathrm{ft}$ & $\mathrm{m}$ & 3.2808 \\
0.0929 & $\mathrm{ft}^{2}$ & $\mathrm{~m}$ & 10.7639 \\
3.7854 & $\mathrm{gal}$ & $\mathrm{L}$ & 0.2642 \\
9.3540 & $\mathrm{gal} / \mathrm{acre}$ & $\mathrm{L} \cdot \mathrm{ha}^{-1}$ & 0.1069 \\
2.54 & inch $(\mathrm{es})$ & $\mathrm{cm}$ & 0.3937 \\
25.4 & inch $(\mathrm{es})$ & $\mathrm{mm}$ & 0.0394 \\
1.1209 & $\mathrm{lb} / \mathrm{acre}$ & $\mathrm{kg} \cdot \mathrm{ha}^{-1}$ & 0.8922 \\
1 & $\mathrm{meq} / 100 \mathrm{~g}$ & $\mathrm{cmol} \cdot \mathrm{kg}^{-1}$ & 1 \\
1 & $\mathrm{mmho} / \mathrm{cm}$ & $\mathrm{dS} \cdot \mathrm{m}^{-1}$ & 1 \\
1.7300 & $\mathrm{oz} / \mathrm{inch}$ & $\mathrm{g} \cdot \mathrm{cm}^{-3}$ & 0.5780 \\
1 & $\mathrm{ppm}$ & $\mathrm{mg} \cdot \mathrm{kg}^{-1}$ & 1 \\
1 & $\mathrm{ppm}$ & $\mathrm{mg} \cdot \mathrm{L}^{-1}$ & 1 \\
6.8948 & $\mathrm{psi}$ & $\mathrm{kPa}$ & 0.1450 \\
0.9072 & ton $(\mathrm{s})$ & $\mathrm{t}$ & 1.1023 \\
$\left({ }^{\circ} \mathrm{F}-32\right) \div 1.8$ & ${ }^{\circ} \mathrm{F}$ & ${ }^{\circ} \mathrm{C}$ & $\left({ }^{\circ} \mathrm{C} \times 1.8\right)+32$
\end{tabular}

Hortlechnology · December 2016 26(6) 
During two cropping seasons in a Mollisol, Drost and Koeing (2002) evaluated onion yield response to fertilizer-N ranging from 112 to $224 \mathrm{~kg} \cdot \mathrm{ha}^{-1}$ of $\mathrm{N}$ and found that $112 \mathrm{~kg} \cdot \mathrm{ha}^{-1}$ increased onion yield with $\mathrm{N}$ applied as urea but not as polymer-coated urea.

Wyenandt et al. (2008) applied $56 \mathrm{~kg} \cdot \mathrm{ha}^{-1}$ of $\mathrm{N}$ the first year and $93 \mathrm{~kg} \cdot \mathrm{ha}^{-1}$ the second year to an Ultisol and did not observe differences in pumpkin (Cucurbita pepo) fruit yield using side-dress $\mathrm{N}$ rates of 28 and $84 \mathrm{~kg} \cdot \mathrm{ha}^{-1}$. Swiader and Shoemaker (2004) determined the effect of various cropping systems (rotations) on fertilizer- $\mathrm{N}$ requirements in processing pumpkin (C. moschata) over a 5-year period in Mollisols using fertilization rates ranging from 0 to $224 \mathrm{~kg} \cdot \mathrm{ha}^{-1}$ of $\mathrm{N}$. When processing pumpkin following soybean (Glycine max), the optimal $\mathrm{N}$ fertilization rate was $110 \mathrm{~kg} \cdot \mathrm{ha}^{-1}$. Harrelson et al. (2008) found that fertilization rates of 80 and $120 \mathrm{~kg} \cdot \mathrm{ha}^{-1}$ of $\mathrm{N}$ produced greater pumpkin (C. pepo) yields and larger fruit size than rates of 0 and $40 \mathrm{~kg} \cdot \mathrm{ha}^{-1}$ in an experiment conducted on Inceptisols at three different experiment stations in North Carolina.

There is limited information on onion and tropical pumpkin response to fertilizer-N in soils of the tropics. Further, there is no published information that describes the environmental impact of fertilizer-N on vegetable production areas in Puerto Rico. Fertilizer-N in excess of crop requirements can result in high residual soil $\mathrm{NO}_{3}-\mathrm{N}$, leached $\mathrm{N}$, and $\mathrm{N}$ losses in runoff, potentially impacting surface and groundwater $\mathrm{NO}_{3}$ concentration. Based on anecdotal information provided by growers, and considering onion growth characteristics, we hypothesize that onion production fertilized with excessive $\mathrm{N}$ potentially contributes to high $\mathrm{N}$ concentrations that have been found in groundwater in Puerto Rico (Rodríguez, 2006). The objectives of this work were 1) to evaluate the effect on agronomic indicators and yield of three fertilizer-N levels in onion and two fertilizer- $\mathrm{N}$ levels in tropical pumpkin, planted in rotation, and 2) to determine the influence of fertilizer- $\mathrm{N}$ rates in this rotation on residual soil $\mathrm{NO}_{3}-\mathrm{N}$.

\section{Materials and methods}

An onion-tropical pumpkinfallow rotation was established on a Guayacán clay (Fine-loamy, mixed, superactive, isohypertermic Typic Haplocalcids) soil on a private farm in Guánica, Puerto Rico. The soil at 0 to $15 \mathrm{~cm}$ depth has a clayey-loam textural classification, a cation exchange capacity (ammonium acetate extractable) of $30.8 \mathrm{meq} / 100 \mathrm{~g}$ ), and soil electrical conductivity of $0.8 \mathrm{dS} \cdot \mathrm{m}^{-1}$ (Table 1 ). The soil has hydrologic soil group D, a $2 \%$ slope and classified as prime farmland if irrigated (U.S. Department of Agriculture, 2008). The experiment was placed within a $400 \times 162-\mathrm{ft}$ area (1.49 acres) of a 6-acre commercial vegetable production field. During the 2 years before beginning the experiment, the field was under an annual rotation common on the south coast of Puerto Rico of 'Aruba' pepper [Capsicum annumm (Seminis, St. Louis, MO)] followed by 'Tropicuke' cucumber [Cucumis sativus (PanDia Seeds, Ojai, CA)] followed by fallow.

Soil preparation included the sequence of disking, sub-soiling, disking, and harrowing. Twenty-seven 400-ft-long raised beds with two drip lines were prepared and divided into three sections of nine beds each. Beds were $4.6 \mathrm{ft}$ wide with $6 \mathrm{ft}$ between bed centers. One of three $\mathrm{N}$ fertilizer treatments (detailed below) was randomly assigned to each 400-ft-long section of nine beds, and each section was divided into four 100-ft-long plots to serve as treatment replicates. Thus, each experimental unit consisted of nine beds $100 \mathrm{ft}$ in length. Since $\mathrm{N}$ treatments were supplied via drip lines that ran the entire length of each 400-ft-long section, treatments were laid out in a systematic fashion rather than being completely randomized. Bias due to lack of true treatment randomization was expected to be small, given the very large plot sizes.

One week after bed preparation a precision vacuum seeder (MaterMacc, San Vito al Tagliamento, Italy) was used to seed 'Mercedes' onion (Seminis) on 22 Oct. 2012. The seeder was manually adjusted to seed eight rows within a bed, at a distance of $16.5 \mathrm{~cm}$ between rows and $7 \mathrm{~cm}$ between seeds in a row. The desired planting density was 614,818 plants/ha. Although the typical germination for onion seed is between $60 \%$ and $80 \%$, the germination rate counted by the grower in the surrounding commercial field (planted in similar manner and time) was $46 \%$.

'Soler' tropical pumpkin (C. González, Guánica, Puerto Rico) was transplanted 15 Apr. 2013 at the two-leaf stage. Tropical pumpkin was planted in the same experimental area used for onion except that in each section of nine beds, the two outside beds were not planted, as done commercially to permit mechanical spraying. Plants were spaced $6 \mathrm{ft}$ apart within beds for the desired density of 1210 plants/acre.

For both onion and tropical pumpkin, dimethenamid-P (Outlook ${ }^{\circledR}$; BASF, Research Triangle Park, NC) was applied uniformly to the soil surface after planting and before crop emergence at the rate of $1 \mathrm{~L} \cdot \mathrm{ha}^{-1}$ as a preemergent herbicide. Glyphosate (Gly Star ${ }^{\circledR}$; Albaugh, Ankeny, IA), at the rate of $1.3 \mathrm{~L} \cdot \mathrm{ha}^{-1}$, was used as

Table 1. Soil fertility characterization [0-15 cm (5.9 inches)] of plots in Guánica, PR before onion planting. ${ }^{\mathrm{z}}$

\begin{tabular}{|c|c|c|c|c|c|c|c|c|c|c|c|c|c|c|c|}
\hline & & $\mathrm{OM}$ & $\mathrm{NO}_{3}-\mathrm{N}$ & Olsen P & $\mathrm{Ca}$ & $\mathrm{Mg}$ & $\mathbf{K}$ & $\mathrm{Na}$ & CEC & $S$ & $\mathrm{Fe}$ & Mn & $\mathrm{Zn}$ & $\mathrm{Cu}$ & B \\
\hline & $\mathrm{pH}$ & $\overline{\left(\mathrm{g} \cdot \mathrm{kg}^{-1}\right)^{\mathrm{y}}}$ & $\overline{\left(\mathrm{mg} \cdot \mathrm{kg}^{-1}\right)^{y}}$ & $\overline{\left(\mathrm{mg} \cdot \mathrm{kg}^{-1}\right)}$ & \multicolumn{5}{|c|}{$(\mathrm{meq} / 100 \mathrm{~g})^{\mathrm{y}}$} & \multicolumn{6}{|c|}{$\left(\mathrm{mg} \cdot \mathrm{kg}^{-1}\right)$} \\
\hline $\operatorname{Mean}^{\mathrm{x}}$ & 8.2 & 2.3 & 58.7 & 16.3 & 20.4 & 8.9 & 1.1 & 0.5 & 30.8 & 20.2 & 6.0 & 1.8 & 1.7 & 5.5 & 1.3 \\
\hline
\end{tabular}

${ }_{\mathrm{z}}^{\mathrm{pH}}\left(\mathrm{l}\right.$ soil: lwater), $\mathrm{OM}=$ organic matter (weight loss on ignition), $\mathrm{NO}_{3}-\mathrm{N}=$ water extractable nitrate nitrogen, $\mathrm{P}=$ phosphorus $(\mathrm{Olsen}-\mathrm{bicarbonate}$ method $), \mathrm{Ca}=$ calcium, $\mathrm{Mg}=$ magnesium, $\mathrm{K}=$ potassium, $\mathrm{Na}=$ sodium (ammonium acetate extractable), $\mathrm{S}=$ sulfate sulfur $\left[\right.$ sulfate sulfur, $\mathrm{K}_{2} \mathrm{HPO}_{4}($ dipotassium phosphate) extractable], $\mathrm{CEC}=$ cation exchange capacity, $\mathrm{Fe}=$ iron, $\mathrm{Mn}=$ manganese, $\mathrm{Zn}=$ zinc, $\mathrm{Cu}=$ copper (DTPA-TEA extraction method), $\mathrm{B}=$ boron $($ hot water extractable).

${ }^{\mathrm{y}} 1 \mathrm{~g} \cdot \mathrm{kg}^{-1}=0.1 \% ; \mathrm{l} \mathrm{mg} \cdot \mathrm{kg}^{-1}=1 \mathrm{ppm} ; 1 \mathrm{meq} / 100 \mathrm{~g}=1 \mathrm{cmol} \cdot \mathrm{kg}^{-1}$.

${ }^{\mathrm{x}}$ Mean of 12 replicates. 
a postemergent herbicide for the tropical pumpkin crop.

Treatment DESCRIPTIONS. In onion, we evaluated fertilizer- $\mathrm{N}$ levels of 140, 196, and $252 \mathrm{~kg} \cdot \mathrm{ha}^{-1}$. Preplant fertilization to the raised beds consisted of broadcasting $22 \mathrm{~kg} \cdot \mathrm{ha}^{-1}$ of $\mathrm{N}, 10 \mathrm{~kg} \cdot \mathrm{ha}^{-1}$ of phosphorus $(\mathrm{P})$, and $33 \mathrm{~kg} \cdot \mathrm{ha}^{-1}$ of potassium $(\mathrm{K})$. The difference between the amount of preplant $\mathrm{N}$ fertilization and the fertilizer-N total of each treatment was applied by fertigation at 10 weekly intervals starting 2 weeks after planting (WAP). Onion fertigations were initiated on 12 Nov. 2012 and ended on 14 Jan. 2013. The sources of fertilizer- $\mathrm{N}$ used were a combination of urea, ammonium sulfate (AS) and potassium nitrate $(\mathrm{PN})$, with $\mathrm{N}$ ratios (urea-N:AS-N:PN-N) of $2: 1: 1$ for $140 \mathrm{~kg} \cdot \mathrm{ha}^{-1}, 2.7: 1.7: 1$ for $196 \mathrm{~kg} \cdot \mathrm{ha}^{-1}$, and 3.5:2.5:1 for $252 \mathrm{~kg} \cdot \mathrm{ha}^{-1}$ treatments. All treatments received the same P level. A total of $139 \mathrm{~kg} \cdot \mathrm{ha}^{-1}$ of $\mathrm{K}$ was applied and potassium sulfate was used as the K source for those treatments that needed supplemental $\mathrm{K}$ fertilization. Variable fertilizer-N rates were applied for each of the 10 fertigations. In general the fertigation treatment consisted of a 15-min irrigation, followed by $30 \mathrm{~min}$ of fertilizer injection, and a final $15-\mathrm{min}$ irrigation.

The tropical pumpkin fertilizer$\mathrm{N}$ treatments were 112 and 280 $\mathrm{kg} \cdot \mathrm{ha}^{-1}$ by fertigation. The low $\mathrm{N}$ treatment was applied to tropical pumpkin in plots previously used for onion at the lowest $\mathrm{N}$ level (140 $\mathrm{kg} \cdot \mathrm{ha}^{-1}$ ) and the high $\mathrm{N}$ treatment was applied to plots previously planted in onion with the highest fertilizer-N treatment $\left(252 \mathrm{~kg} \cdot \mathrm{ha}^{-1}\right)$. Eight fertigations were applied over a 10-week period. For both onion and tropical pumpkin, the irrigation water had $4 \mathrm{mg} \cdot \mathrm{L}^{-1} \mathrm{NO}_{3}-\mathrm{N}$ and was estimated to contribute $1 \mathrm{~kg} \cdot \mathrm{ha}^{-1}$ of $\mathrm{N}$ for every inch of water applied.

Plant measurements. For onion, plant density, number of leaves, plant height, sap $\mathrm{NO}_{3}$, and leaf color were measured at 7 and 10 WAP. Within a plot, observations were made on 10 randomly selected plants within a randomly placed $16-\mathrm{ft}^{2}$ quadrant. The date at which $50 \%$ or more of the plants had bulbs was recorded. Leaf color (plant greenness) was assessed on a scale of 1 to 4 using the IRRI Leaf Color Chart
(Witt et al., 2005). Fifteen plants from each plot were sampled for leaf nutrient indicators on 25 Jan. 2013 [95 d after planting (DAP)]. Leaves were analyzed for total elemental analysis [N, P, K, calcium (Ca), magnesium $(\mathrm{Mg})$, sulfur $(\mathrm{S})$, iron $(\mathrm{Fe})$, manganese $(\mathrm{Mn})$, zinc $(\mathrm{Zn})$, copper $(\mathrm{Cu})$, and boron (B)] by AgSource Laboratories (Bonduel, WI). Data from leaf nutrient indicators was combined across all fertilizer- $\mathrm{N}$ treatments and used to calculate 95\% confidence limits (CL). At maturity, plant vegetative and fruit biomass were estimated for each plot. Aboveground plant biomass from 10 plants was cut at ground level. All vegetative material was weighed and a subsample was analyzed for moisture to determine the vegetative biomass dry weight. Onion bulbs were harvested 1 Mar. 2013. Bulb tops were cut, and bulbs were lifted and allowed to dry for several days. Bulbs were then harvested by hand from a $20-\mathrm{ft}$ segment of one of the middle beds of a nine-bed plot. Harvested bulbs were separated into size classes of extra small (< 1.75-inch diameter), small (1.75- to 2 -inch diameter), medium (2- to 3-inch diameter), large [or jumbo (3- to 3.75-inch diameter)], and colossal (>3.75-inch diameter), counted and weighed. The mature air-dried aboveground vegetative plant material and the bulbs were analyzed for total elemental analysis as specified previously. A subsample of bulbs was analyzed for moisture to estimate bulb dry weight. Nutrient extraction was calculated based on the nutrient concentration and the bulb dry matter, and nutrient uptake was calculated based on the nutrient concentration and vegetative dry matter. Onion had a mean moisture content of 919.1 g water per kilogram fresh weight.

A random sample of 15 tropical pumpkin leaves per plot were taken 8 July 2013 (85 DAP) and analyzed for total elemental analysis in the same manner as for onion. Fruit from all seven beds of tropical pumpkin plots were harvested, counted and weighed 19 July 2013. Vegetative biomass dry weight was estimated by harvesting plant material in a $1-\mathrm{m}^{2}$ quadrant and correcting for percentage moisture. Fruit biomass dry weight was estimated from a subsample of all harvested fruits.
SoIl measurements. Soil was sampled within each plot before onion planting, during the onion growing period, at the end of the onion harvest, and at the end of the tropical pumpkin harvest. Soils were sampled pre-plant and post-harvest at $0-15$, 15-30, 30-60, and 60-100 cm. On occasion, additional samples were taken when a soil textural discontinuity was observed. Soils were stored in plastic bags and transferred to the laboratory and air-dried and then sieved to pass a 4-mm mesh. Air-dried and sieved soil samples were stored in the bags in the laboratory until analysis.

The surface 0 to $15 \mathrm{~cm}$ soil interval was analyzed for soil fertility parameters by AgSource Laboratories (Lincoln, NE). Profile soil samples were analyzed for $1 \mathrm{M}$ potassium chloride $(\mathrm{KCl})$ extractable ammonium-N $\left(\mathrm{NH}_{4}{ }^{+}-\mathrm{N}\right.$ ) and $\mathrm{NO}_{3}-\mathrm{N}$ (inorganic $\mathrm{N})$. Inorganic $\mathrm{N}$ concentrations were expressed on a kilogram-per-hectare basis after correcting for the corresponding sampling depth interval 1 and a soil bulk density of $1.35 \mathrm{~g} \cdot \mathrm{cm}^{-3}$. Immediately available $\mathrm{N}$ was estimated as the amount of inorganic $\mathrm{N}$ within the 0 - to $15-\mathrm{cm}$ and $15-$ to $30-\mathrm{cm}$ depth intervals. Potentially leached $\mathrm{N}$ was estimated as the inorganic $\mathrm{N}$ within the $30-$ to $60-\mathrm{cm}$ and 60 - to $100-\mathrm{cm}$ depth intervals. Total profile $\mathrm{N}$ was estimated as the depth integrated $\mathrm{NO}_{3}-\mathrm{N}$ concentration to a depth of $100 \mathrm{~cm}$.

Climatologic data and IRRIgATION. Precipitation and air temperature data were gathered from a nearby weather station. Each raised bed contained two drip irrigation lines (Chapin ${ }^{\mathrm{TM}}$; Jain Irrigation Systems, Maharashtra, India) with a flow of $0.152 \mathrm{gal} / \mathrm{min}$ per $100 \mathrm{ft}$ at $10 \mathrm{psi}$ with 12 inches between emitters. Soil water in selected beds was monitored during the onion growing season with tensiometers (Model "R"; Irrometer Co., Riverside, CA) placed in the seed row at a depth of $20 \mathrm{~cm}$. The field was irrigated 24 times during the growing season for a total irrigation depth of $18.54 \mathrm{~cm}$. The field was irrigated when tensiometers indicated soil moisture of less than $-30 \mathrm{kPa}$.

SOIL-SOLUTION COMPOSITION EVALUATION. Eight suction-cup lysimeters (Irrometer Co.) were installed at 6- and 12-inch depths. Four lysimeters were placed in the 
lowest fertilizer- $\mathrm{N}$ treatment plots during onion production and four were placed in the highest fertilizer$\mathrm{N}$ treatment plots, each at two soil depths, 6 and 12 inches. Data were collected from three fertigation events during onion production. To obtain a soil solution, a tension of about $-80 \mathrm{kPa}$ was applied, and between 8 and 12 h later, soil solution samples were obtained. Samples were taken before, during, and after fertilizer application. Samples were stored frozen until analysis for electrical conductivity and $\mathrm{NO}_{3}$ and $\mathrm{NH}_{4}$ (AgSource Laboratories).

ECONOMIC ANALYsIs. Final harvest yields were expressed as fresh onion or tropical pumpkin weight per hectare. Estimated onion gross return per hectare was calculated based on harvest prices of $\$ 783 / \mathrm{t}$ for jumbo and colossal, $\$ 712.8 / \mathrm{t}$ for large, $\$ 557 / \mathrm{t}$ for medium, and $\$ 402.6 / \mathrm{t}$ for small bulbs. The harvest price of tropical pumpkin was $\$ 0.35$ / $\mathrm{kg}$ of fruit (C. González, personal communication). The only variable cost was $\mathrm{N}$ fertilizer depending on the fertilizer level applied. All other costs were considered fixed.

Statistical analysis. Analyses of variance (completely randomized design) were performed using InfoStat (Di Rienzo et al., 2014) to test treatment effects. All statistical comparisons were made at $P<0.05$ and means separation was done with Fisher's least significant difference test when appropriate.

\section{Results and discussion}

The total precipitation was $358 \mathrm{~mm}$ (occurring on $27 \mathrm{~d}$ ) during onion production and $259 \mathrm{~mm}$ (occurring on $23 \mathrm{~d}$ ) during tropical pumpkin production. There were 107 and $89 \mathrm{~d}$ without precipitation during the crop growth cycle of onion and tropical pumpkin, respectively. Mean maximum and minimum temperatures were 31.0 and $17.4{ }^{\circ} \mathrm{C}$, respectively.

The soil had characteristics that are typical for Mollisols in Puerto Rico with intensive cropping conditions (Table 1). The low organic matter observed may reflect years of continuous vegetable cropping with continuous tillage and low levels of vegetative residue return to the soil. Olsen-bicarbonate extractable P levels were highly variable and were below sufficiency levels in most plots, thus fertilizer-P added at planting was expected to alleviate potential $\mathrm{P}$ deficiency. Micronutrients, extractable bases, and sulfate sulfur $\left(\mathrm{SO}_{4}-\mathrm{S}\right)$ were above suggested sufficiency levels for onion [University of Puerto Rico, Agricultural Experiment Station (UPR-AES), 2012a]. Extractable (1M $\mathrm{KCl}) \mathrm{NO}_{3}-\mathrm{N}$ levels were highly variable with $\mathrm{cv}$ from $78 \%$ to $133 \%$ within each treatment and $86 \%$ across all of the experiment.

ONION AGRONOMIC INDICATORS. Mean onion plant density was low due to poor seed germination ranging from 304,287 to 326,142 plants/ha with no differences among $\mathrm{N}$ treatments. The highest fertilizer- $\mathrm{N}$ treatment resulted in faster bulb formation (bulb formation was defined as swelling has begun $)$ at $10 \mathrm{WAP}(P<0.05)$ with $55 \%$ of the plants having bulbs as compared with $29 \%$ and $33 \%$ with the 140 and $196 \mathrm{~kg} \cdot \mathrm{ha}^{-1} \mathrm{~N}$ treatments, respectively. One week later, $69 \%$ of the plants had bulbs, and there was no significant difference among treatments. Previous reports from Puerto Rico suggest that high $\mathrm{N}$ fertilization rates are associated with prolongation of bulb formation (UPR-AES, 2012a).
At 7 and $10 \mathrm{WAP}$, there were some differences $(P<0.05)$ in onion plant height and number of leaves among the three $\mathrm{N}$ fertilizer rates (Table 2). However, the trends were not in a consistent direction, and there were no differences in plant height and number of leaves between the low $\left(140 \mathrm{~kg} \cdot \mathrm{ha}^{-1}\right)$ and high $(252$ $\mathrm{kg} \cdot \mathrm{ha}^{-1}$ ) fertilizer-N treatments.

Onion leaf color (an indication of $\mathrm{N}$ status) did not vary among $\mathrm{N}$ treatments at either 7 or 10 WAP (Table 2). At both 7 and 10 WAP, onion sap $\mathrm{NO}_{3}-\mathrm{N}$ was significantly greater $(P<0.05)$ for the highest fertilizer-N treatment $\left(252 \mathrm{~kg} \cdot \mathrm{ha}^{-1}\right)$ compared with the intermediate $\mathrm{N}$ rate $\left(196 \mathrm{~kg} \cdot \mathrm{ha}^{-1}\right)$.

We also looked at leaf $\mathrm{K}, \mathrm{Ca}, \mathrm{Mg}$, $\mathrm{S}, \mathrm{Fe}, \mathrm{Mn}, \mathrm{Zn}, \mathrm{Cu}$, and $\mathrm{B}$ (data not shown). Due to the general lack of clear treatment effects, we used the means averaged over the three $\mathrm{N}$ fertilizer treatments to calculate the $\pm 95 \%$ CL for each nutrient (Table 3). These CL can be used as a guide to improve the local database in regards to leafbased sufficiency levels in onion.

OnION NUTRIENT UPTAKe. Onion bulb biomass and bulb $\mathrm{N}$ represented $57 \%$ and $54 \%$ of the total biomass and $\mathrm{N}$ uptake, respectively (Table 4). The mean harvest index across treatments was 0.57 and unaffected by fertilizer-N levels. Of all nutrients taken up by the crop (biomass plus bulb), the highest rate of nutrient uptake occurred for K. An estimated $171 \mathrm{~kg} \cdot \mathrm{ha}^{-1}$ of K was taken up, of which $45 \%$ was removed in the harvested portion (onion bulb) of the plant. Fertilizer-N uptake was $123 \mathrm{~kg} \cdot \mathrm{ha}^{-1}$, which was lower than the lowest fertilizer- $\mathrm{N}$ rate applied. Of the total biomass $\mathrm{N}$ removed, nearly $46 \%$ was expected to be returned and recycled to the soil for the next crop.

Table 2. Agronomic indicators [mean plant height, number of leaves, leaf color, sap nitrate nitrogen $(\mathrm{N})$ ] of onion planted in Guánica, PR as influenced by fertilizer $\mathrm{N}$ levels at 7 and 10 weeks after planting.

\begin{tabular}{|c|c|c|c|c|c|c|c|c|}
\hline \multirow[b]{2}{*}{$\begin{array}{l}\text { Fertilizer } \mathrm{N} \\
\text { rate }\left(\mathrm{kg} \cdot \mathrm{ha}^{-1}\right)^{\mathrm{z}}\end{array}$} & \multicolumn{4}{|c|}{ Wk 7} & \multicolumn{4}{|c|}{ Wk 10} \\
\hline & $\begin{array}{c}\text { Plant ht } \\
(\mathrm{cm} / \text { plant })^{\mathrm{z}}\end{array}$ & $\begin{array}{c}\text { Leaves } \\
\text { (no./plant) }\end{array}$ & $\begin{array}{l}\text { Leaf color } \\
\text { index } \\
(1-4 \text { scale })^{y}\end{array}$ & $\begin{array}{c}\text { Sap nitrate } N \\
\left(\mathbf{m g} \cdot \mathrm{kg}^{-1}\right)^{\mathrm{z}}\end{array}$ & $\begin{array}{c}\text { Plant ht } \\
(\mathrm{cm} / \text { plant })\end{array}$ & $\begin{array}{c}\text { Leaves } \\
\text { (no./plant) }\end{array}$ & $\begin{array}{c}\text { Leaf color } \\
\text { index } \\
(1-4 \text { scale })\end{array}$ & $\begin{array}{c}\text { Sap nitrate N } \\
\left(\mathrm{mg} \cdot \mathrm{kg}^{-1}\right)\end{array}$ \\
\hline 196 & 37.1 & $5.7 \mathrm{ab}$ & 2.9 & $425 \mathrm{a}$ & $64.6 \mathrm{a}$ & $8.6 \mathrm{a}$ & 3.0 & $295.0 \mathrm{a}$ \\
\hline 252 & 40.3 & $6.0 \mathrm{~b}$ & 3.0 & $582 \mathrm{~b}$ & $69.2 \mathrm{~b}$ & $9.8 \mathrm{~b}$ & 3.0 & $372.5 \mathrm{~b}$ \\
\hline
\end{tabular}

${ }^{\mathrm{z}} \mathrm{l} \mathrm{kg} \cdot \mathrm{ha}^{-1}=0.8922 \mathrm{lb} /$ acre$; \mathrm{l} \mathrm{cm}=0.3937 \mathrm{inch} ; \mathrm{l} \mathrm{mg} \cdot \mathrm{kg}^{-1}=1 \mathrm{ppm}$.

y IRRI Leaf Color Chart where 1 = less intensive green color to $4=$ most intensive green color (Witt et al., 2005).

${ }^{x}$ Within a column, means followed by the same letter are not statistically different according to the least significant difference test at the $0.05 P$ level. 
Table 3. Upper (+ ) and lower ( - ) 95\% confidence limits (CL) of sufficiency levels of nutrients in indicator leaves sampled 11 weeks after transplanting onion under three nitrogen $(\mathrm{N})$ fertilizer levels in Guánica, PR. ${ }^{\mathrm{z}}$

\begin{tabular}{|c|c|c|c|c|c|c|c|c|c|c|c|}
\hline & $\mathbf{N}$ & $\mathbf{P}$ & $\mathbf{K}$ & $\mathrm{Ca}$ & Mg & $S$ & $\mathrm{Fe}$ & Mn & $\mathrm{Zn}$ & $\mathrm{Cu}$ & B \\
\hline & \multicolumn{6}{|c|}{$\ldots \ldots \ldots \ldots \ldots \ldots\left(\mathrm{g} \mathrm{kg}^{-1}\right)^{\mathrm{y}} \ldots \ldots \ldots \ldots \ldots \ldots$} & \multicolumn{5}{|c|}{$\ldots \ldots \ldots \ldots \ldots\left(\mathrm{mg} \cdot \mathrm{kg}^{-1}\right)^{\mathrm{y}} \ldots \ldots \ldots \ldots \ldots$} \\
\hline$-95 \%$ CL & 47.7 & 2.5 & 38.9 & 13.14 & 5.37 & 11.1 & 191.6 & 38.9 & 28.4 & 19.1 & 24.5 \\
\hline$+95 \% \mathrm{CL}$ & 51.0 & 3.0 & 47.4 & 16.03 & 6.69 & 12.8 & 269.1 & 50.3 & 40.6 & 25.2 & 30.5 \\
\hline
\end{tabular}

${ }^{\mathrm{z}} \mathrm{CL}$ were calculated using the mean of the three $\mathrm{N}$ fertilizer treatment levels; $\mathrm{P}=$ phosphorus, $\mathrm{K}=$ potassium, $\mathrm{Ca}=\mathrm{calcium}, \mathrm{Mg}=\mathrm{magnesium}, \mathrm{S}=$ sulfur, $\mathrm{Fe}=$ iron, $\mathrm{Zn}=\mathrm{zinc}$, $\mathrm{Mn}=$ manganese, $\mathrm{Cu}=$ copper, $\mathrm{B}=$ boron.

${ }^{\mathrm{y}} \mathrm{l} \mathrm{g} \cdot \mathrm{kg}^{-1}=0.1 \% ; \mathrm{l} \mathrm{mg} \cdot \mathrm{kg}^{-1}=1 \mathrm{ppm}$.

Table 4. Mean plant dry weight, harvest index, nitrogen $(\mathrm{N})$ concentration and $\mathrm{N}$ extraction in vegetation, bulbs and fruit harvested from an onion, and tropical pumpkin rotation in Guánica, PR under varying levels of $\mathrm{N}$ fertilization.

\begin{tabular}{|c|c|c|c|c|c|c|c|c|c|}
\hline \multirow[b]{2}{*}{$\begin{array}{l}\text { Fertilizer } \\
\text { N level } \\
\left(\mathbf{k g} \cdot \mathrm{ha}^{-1}\right)^{\mathrm{z}} \\
\end{array}$} & \multicolumn{3}{|c|}{ Plant dry wt } & \multirow[b]{2}{*}{$\begin{array}{c}\text { Harvest } \\
\text { index }^{\mathrm{y}}\end{array}$} & \multicolumn{2}{|c|}{$\mathbf{N}$ concn } & \multicolumn{3}{|c|}{$\mathbf{N}$ extraction } \\
\hline & $\begin{array}{l}\text { Vegetative } \\
\left(\mathrm{kg} \cdot \mathrm{ha}^{-1}\right)\end{array}$ & $\begin{array}{c}\text { Bulb or } \\
\text { fruit } \\
\left(\mathrm{kg} \cdot \mathrm{ha}^{-1}\right)\end{array}$ & $\begin{array}{c}\text { Vegetative }+ \\
\text { bulb or fruit } \\
\left(\mathrm{kg} \cdot \mathrm{ha}^{-1}\right)\end{array}$ & & $\begin{array}{c}\text { Vegetative } \\
\left(\mathrm{g} \cdot \mathrm{kg}^{-1}\right)^{\mathrm{z}}\end{array}$ & $\begin{array}{c}\text { Bulb or } \\
\text { fruit } \\
\left(\mathrm{g} \cdot \mathrm{kg}^{-1}\right)\end{array}$ & $\begin{array}{l}\text { Vegetative } \\
\left(\mathrm{kg} \cdot \mathrm{ha}^{-1}\right)\end{array}$ & $\begin{array}{c}\text { Bulb or } \\
\text { fruit } \\
\left(\mathrm{kg} \cdot \mathrm{ha}^{-1}\right)\end{array}$ & $\begin{array}{c}\text { Vegetative }+ \\
\text { bulb or fruit } \\
\left(\mathrm{kg} \cdot \mathrm{ha}^{-1}\right)\end{array}$ \\
\hline \multicolumn{10}{|l|}{ Onion } \\
\hline 140 & 2,258 & 3,050 & 5,307 & 0.57 & 23.2 & 19.6 & 52 & 59 & 111 \\
\hline 196 & 2,408 & 2,930 & 5,337 & 0.54 & 24.5 & 22.5 & 59 & 64 & 122 \\
\hline$P($ F test $)$ & 0.8513 & 0.6613 & 0.6876 & 0.6970 & 0.3735 & 0.3950 & 0.7154 & 0.2284 & 0.2691 \\
\hline \multicolumn{10}{|c|}{ Tropical pumpkin } \\
\hline 112 & 2,339 & 5,523 & 7,862 & 0.70 & 27.6 & 27.7 & 64 & 155 & 219 \\
\hline 280 & 3,425 & 6,097 & 9,522 & 0.64 & 27.9 & 31.1 & 91 & 188 & 279 \\
\hline Mean & 2,882 & 5,810 & 8,692 & 0.67 & 27.8 & 29.4 & 78 & 172 & 249 \\
\hline$P($ F test $)$ & 0.1688 & 0.5461 & 0.1924 & 0.3569 & 0.8899 & 0.2305 & 0.0293 & 0.2933 & 0.0694 \\
\hline
\end{tabular}

${ }^{\mathrm{z}} 1 \mathrm{~kg} \cdot \mathrm{ha}^{-1}=0.8922 \mathrm{lb} / \mathrm{acre} ; \mathrm{l} \mathrm{g} \cdot \mathrm{kg}^{-1}=0.1 \%$.

${ }^{\mathrm{y}}$ Harvest index calculated as fruit biomass dry weight/[vegetative + bulb (onion) or fruit (tropical pumpkin) dry weight].

ONION SIZE CLASSIFICATION. Onion size classification was unaffected by fertilizer-N levels (data not shown). The colossal size class was less than $3 \%$ of all marketable onions and the small-size classification was less than $12 \%$ of all onions. As expected for the variety planted, an average of between $54 \%$ and $61 \%$ of the onions were in the medium-size class and between $21 \%$ and $29 \%$ were in the large-size class.

ONION YIELD. All of the harvested material was free from visible pathogens. Only 5\% or less of the total harvest was not commercially acceptable. Fertilizer-N rate did not affect the number of marketable bulbs (mean of 173,942 bulbs/ha) or marketable onion yield (mean of $40,168 \mathrm{~kg} \cdot \mathrm{ha}^{-1}$ ) (Table 5 ). Marketable yields in this study were similar to typical yields for onions for the growing conditions of Puerto Rico, estimated at $39,282 \mathrm{~kg} \cdot \mathrm{ha}^{-1}$ (UPRAES, 2012a). The experimental field had fertilizer- $\mathrm{N}$ applications of 175 $\mathrm{kg} \cdot \mathrm{ha}^{-1}$ of $\mathrm{N}$ during the 2 years before the study. These rates of fertilizer- $\mathrm{N}$ added may have resulted in large

Table 5. Means of number and yield of onion bulbs and tropical pumpkin fruit under various levels of nitrogen $(\mathrm{N})$ fertilization in Guánica, PR.

\begin{tabular}{lcc}
\hline $\begin{array}{l}\text { Fertilizer } \mathbf{N} \\
\text { level }\left(\mathbf{k g} \cdot \mathbf{h a}^{-1}\right)^{\mathbf{z}}\end{array}$ & $\begin{array}{c}\text { Marketable bulbs } \\
\text { or fruit (no./ha) }\end{array}$ & $\begin{array}{c}\text { Marketable bulb or } \\
\text { fruit yield }\left(\mathbf{k g} \cdot \mathbf{h a} \mathbf{-}^{-1}\right)\end{array}$ \\
\hline Onion & & \\
140 & 159,298 & 35,888 \\
196 & 177,529 & 38,046 \\
252 & 185,001 & 41,310 \\
$P$ (F test) & 0.3980 & 0.2753 \\
Tropical pumpkin & & \\
112 & 5,738 & 29,274 \\
280 & 8,495 & 44,645 \\
$P$ (F test) & 0.0099 & 0.0055 \\
\hline
\end{tabular}

${ }^{\mathrm{z}} 1 \mathrm{~kg} \cdot \mathrm{ha}^{-1}=0.8922 \mathrm{lb} / \mathrm{acre} ; \mathrm{l}$ bulb or fruit $/ \mathrm{ha}=0.4047 \mathrm{bulb}$ or fruit/acre.

amounts of residual soil $\mathrm{N}$, part of which could have been available during the $2012-13$ onion growing season. Other experiments in Puerto Rico and other areas have shown no response to fertilizer- $\mathrm{N}$ as a result of previous $\mathrm{N}$ fertilization or in the case of Halvorson et al. (2008) when onion followed soybean in rotation. The mean preplant soil $\mathrm{NO}_{3}-\mathrm{N}(0$ to $30 \mathrm{~cm}$ ) was $95.7 \mathrm{~kg} \cdot \mathrm{ha}^{-1}$ of N (Fig. 1), and could explain lack of response above the $140 \mathrm{~kg} \cdot \mathrm{ha}^{-1}$ of $\mathrm{N}$ fertilizer treatment.
The results suggest that onion growers can take a conservative approach to fertilizer- $\mathrm{N}$ application for onion production in situations similar to that of the experimental location of in Guánica, Puerto Rico, including similar historical rotations and nutrient management programs. $\mathrm{N}$ fertilizer rates of less than $140 \mathrm{~kg} \cdot \mathrm{ha}^{-1}$ can result in optimum onion yields, compared with the usual over $200 \mathrm{~kg} \cdot \mathrm{ha}^{-1}$ of $\mathrm{N}$ used by many vegetable producers in Puerto Rico. 

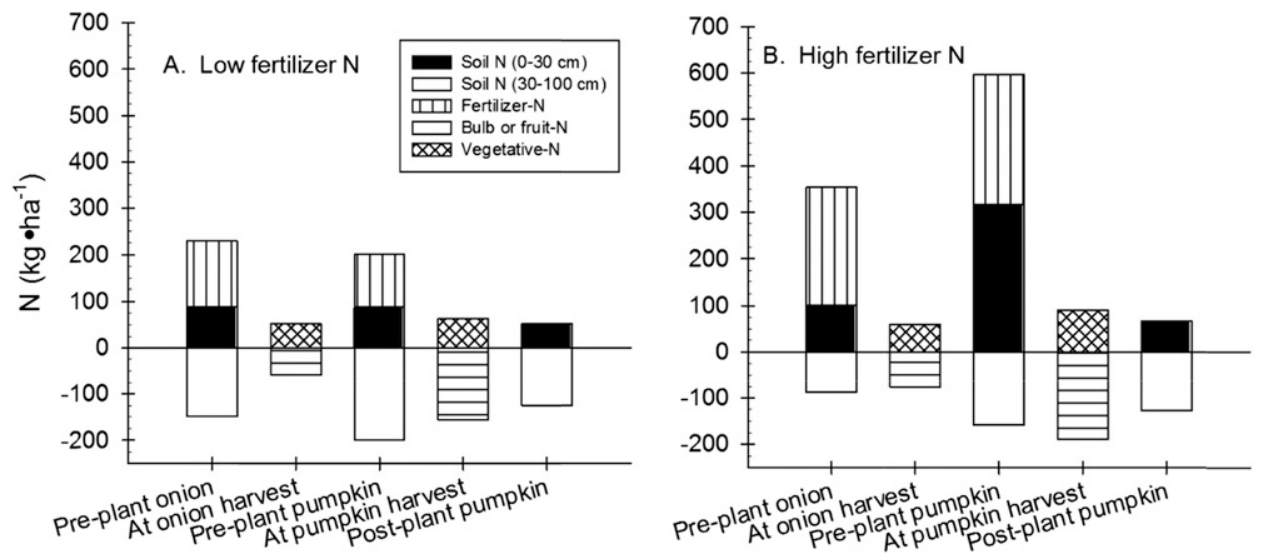

Fig. 1. Partial soil and crop nitrogen $(\mathrm{N})$ budget in plots in Guánica, PR planted in an onion-tropical pumpkin rotation and receiving (A) low or (B) high levels of fertilizer $\mathrm{N}$. Low fertilizer $\mathrm{N}$ plots (A) received $140 \mathrm{~kg} \cdot \mathrm{ha}^{-1} \mathrm{~N}$ before onion planting, followed by $112 \mathrm{~kg} \cdot \mathrm{ha}^{-1} \mathrm{~N}$ before tropical pumpkin planting, for a total of $252 \cdot \mathrm{kg} \cdot \mathrm{ha}^{-1} \mathrm{~N}$. High fertilizer $\mathrm{N}$ plots $(\mathrm{B})$ received $252 \mathrm{~kg} \cdot \mathrm{ha}^{-1} \mathrm{~N}$ before onion planting, followed by $280 \mathrm{~kg} \cdot \mathrm{ha}^{-1} \mathrm{~N}$ before tropical pumpkin planting, for a total of $532 \mathrm{~kg} \cdot \mathrm{ha}{ }^{-1} \mathrm{~N}$. Soil $\mathrm{N}$ values are averages over plots. $\mathrm{N}$ below the horizontal line was considered unavailable (soil $\mathrm{N}$ at a depth equal to or greater than $30 \mathrm{~cm}$ and $\mathrm{N}$ in onion bulbs or pumpkin fruit harvested and removed from the field). $\mathrm{N}$ above the horizontal line was considered available to the onion crop, to the following tropical pumpkin crop, and to the crop that would follow this rotation. $\mathrm{N}$ available at the end of one crop period was added to the positive budget of the following crop period; $1 \mathrm{~kg} \cdot \mathrm{ha}^{-1}=$ $0.8922 \mathrm{lb} / \mathrm{acre}, 1 \mathrm{~cm}=0.3937 \mathrm{inch}$.

Tropical PUMPKIN NUTRIENT UPTAKE. Tropical pumpkin produced an average total dry weight of 8692 and $249 \mathrm{~kg} \cdot \mathrm{ha}^{-1}$ of $\mathrm{N}$, respectively; fruit dry matter and fruit $\mathrm{N}$ represented $67 \%$ and $69 \%$ of the total, respectively (Table 4 ). Mean harvest index across treatments was 0.67 and unaffected by fertilizer-N levels. $\mathrm{N}$ uptake was highest for the $280 \mathrm{~kg} \cdot \mathrm{ha}^{-1}$ of $\mathrm{N}$ treatment, which removed $279 \mathrm{~kg} \cdot \mathrm{ha}^{-1}$ of $\mathrm{N}$, of which $67 \%$ was removed in the harvested portion (pumpkin fruit) of the plant. In plots of the lower fertilizer$\mathrm{N}$ treatment, tropical pumpkin fruit removed $70 \%$ of the total $\mathrm{N}$ uptake.

Tropical PUMPKIN YIELD. Both the number and yield of marketable fruit of tropical pumpkin was about $50 \%$ greater in the high fertilizer-N treatment $\left(280 \mathrm{~kg} \cdot \mathrm{ha}^{-1}\right)$ (Table 5 ). Yields were similar to those previously reported for 'Soler' tropical pumpkin (Wessel-Beaver, 2005). About $4.6 \%$ of the total harvest was not commercially acceptable. The preplant tropical pumpkin profile $(0$ to $100 \mathrm{~cm}$ ) of $\mathrm{NO}_{3}-\mathrm{N}$ was greater than $200 \mathrm{~kg} \cdot \mathrm{ha}^{-1}$ of N (Fig. 1), and in spite of this, there was a crop response to fertilizer-N.

ECONOMIC ANALYSIS FOR ONION AND TROPICAL PUMPKIN PRODUCTION. Fertilizer- $\mathrm{N}$ and complementary nutrients $(\mathrm{P}, \mathrm{K}$, and micronutrients) costs ranged from $\$ 632 /$ ha to \$945/ha for onion and from \$570/ ha to $\$ 1110 /$ ha for the additional fertilizers added to the following tropical pumpkin crop. Estimated production costs (at 2012 prices) for onion and tropical pumpkin were $\$ 20,258 /$ ha (UPR-AES, 2012a) and $\$ 6200 /$ ha, respectively (UPRAES, 2012b). Fertilizer-N used in this experiment represented $3.1 \%$ to $2.8 \%$ of estimated production costs in onion and $9.2 \%$ to $17.9 \%$ of the estimated production costs in tropical pumpkin. The gross profit obtained for onion production was typical for similar locations in Puerto Rico (UPR-AES, 2012a). The gross profits estimated based on yields obtained in our experiment were at or near the farmer's production costs estimated at $\$ 19,690 / \mathrm{ha}$, using $195 \mathrm{~kg} \cdot \mathrm{ha}^{1}$ of N (C. González, personal Communication). In tropical pumpkin, for each additional \$1.00 invested above 112 $\mathrm{kg} \cdot \mathrm{ha}^{-1}$ of $\mathrm{N}$ there was a benefit of $\$ 11.30$ for $280 \mathrm{~kg} \cdot \mathrm{ha}^{-1}$ of $\mathrm{N}$, respectively (Table 6 ).

Residual soll $\mathrm{NO}_{3}-\mathrm{N}$. To examine if there was an increase in soil profile inorganic $\mathrm{N}$ as a result of fertilizer- $\mathrm{N}$ application, we performed a partial soil and crop-N budget for the onion-tropical pumpkin rotation in the low $\left(140 \mathrm{~kg} \cdot \mathrm{ha}^{-1}\right.$ for onion $+112 \mathrm{~kg} \cdot \mathrm{ha}^{-1}$ for tropical pumpkin $=252 \mathrm{~kg} \cdot \mathrm{ha}^{-1}$ ) and high $\left(252 \mathrm{~kg} \cdot \mathrm{ha}^{-1}\right.$ for onion $+280 \mathrm{~kg} \cdot \mathrm{ha}^{-1}$ for tropical pumpkin $=532 \mathrm{~kg} \cdot \mathrm{ha}^{-1}$ )
fertilizer-N plots. Before onion planting, there was similar soil inorganic $\mathrm{N}$ at $0-30 \mathrm{~cm}$ (available $\mathrm{N}$ ) but greater potentially leached $\mathrm{N}$ at the $252 \mathrm{~kg} \cdot \mathrm{ha}^{-1} \mathrm{~N}$ treatment (Fig. 1). At onion harvest, similar amounts of $\mathrm{N}$ were removed in the onion bulb and vegetative dry matter in both fertilizer-N treatments. If applied fertilizer- $\mathrm{N}$, irrigation- $\mathrm{N}$, and $\mathrm{N}$ in the soil at 0 to $30 \mathrm{~cm}$ were all considered as available to the crop, then $25 \%$ and $47 \%$ of available $\mathrm{N}$ was removed in the onion bulb and total crop, respectively, at the lowest fertilizer- $\mathrm{N}$ treatment, and $21 \%$ and $37 \%$ of available $\mathrm{N}$ was removed in the same crop pools at the highest fertilizer-N treatment. The lower crop-N use efficiency under the highest fertilizer- $\mathrm{N}$ treatment is reflected in the greater amount of soil $\mathrm{N}$ at 0 to $30 \mathrm{~cm}\left(316 \mathrm{~kg} \cdot \mathrm{ha}^{-1}\right)$ remaining after onion harvest and before tropical pumpkin planting in plots receiving $252 \mathrm{~kg} \cdot \mathrm{ha}^{-1} \mathrm{~N}$, compared with plots receiving $140 \mathrm{~kg} \cdot \mathrm{ha}^{-1} \mathrm{~N}$ (which had $158 \mathrm{~kg} \cdot \mathrm{ha}^{-1}$ soil $\mathrm{N}$ at 0 to $30 \mathrm{~cm}$ ). When tropical pumpkin was harvested, $66 \%$ of the available $\mathrm{N}$ was used by the crop (fruit and vegetative) for the low fertilizer-N treatment while only $42 \%$ of the available $\mathrm{N}$ was used by the crop in the high fertilizer- $\mathrm{N}$ treatment.

When the soil was re-sampled nearly 1 year after onion was first planted, similar soil $\mathrm{N}$ amounts were 
found in the soil profile at both $0-30$ and $30-100 \mathrm{~cm}$ (Fig. 1). Thus we presume that the difference in the $\mathrm{N}$ use efficiency between the 252 and $532 \mathrm{~kg} \cdot \mathrm{ha}^{-1}$ fertilizer- $\mathrm{N}$ treatments resulted in $\mathrm{N}$ losses by leaching, volatilization, denitrification, and any runoff that occurred after tropical pumpkin planting and before soil sampling. The estimated amount of $\mathrm{N}$ losses can be calculated based on the differences between the amounts of $\mathrm{N}$ applied and the $\mathrm{N}$ removed in the crop and not measured in the soil. We assumed an annual soil-N mineralization rate of $80 \mathrm{~kg} \cdot \mathrm{ha}^{-1}$ of $\mathrm{N}$ for both treatments (D. Sotomayor, unpublished data). In the low fertilizer- $\mathrm{N}$ treatments a net gain of $24 \mathrm{~kg} \cdot \mathrm{ha}^{-1}$ of $\mathrm{N}$ to the soil was estimated, with $124 \mathrm{~kg} \cdot \mathrm{ha}^{-1}$ of $\mathrm{N}$ remaining in the soil profile below the rooting zone at 30 to $100 \mathrm{~cm}$. In the high fertilizer- $\mathrm{N}$ treatment a potential net loss of $175 \mathrm{~kg} \cdot \mathrm{ha}^{-1}$ of $\mathrm{N}$ from the soil was estimated with 126 $\mathrm{kg} \cdot \mathrm{ha}^{-1}$ of $\mathrm{N}$ remaining in the soil profile below the rooting zone.

SoIl solution N. The observed increase in soil profile $\mathrm{N}$ with increasing fertilizer- $\mathrm{N}$ addition should also have been reflected in soil solution measurements taken during the course of the onion growth period. Each fertigation event delivered an estimated 14 and $28 \mathrm{~kg} \cdot \mathrm{ha}^{-1}$ of $\mathrm{N}$ for the low and high fertilizer- $\mathrm{N}$ treatments, respectively. Based on the irrigation water volume and soil moisture percentage, the theoretical solution concentration was calculated as between 73 and $150 \mathrm{mg} \cdot \mathrm{L}^{-1}$ of $\mathrm{N}$ for the low and high fertilizer- $\mathrm{N}$ treatments, respectively. Fifty percent of the $\mathrm{N}$ was in urea form and $25 \%$ and $14 \%$ of the $\mathrm{N}$ was in $\mathrm{NO}_{3}$ form for the low and high fertilizer- $\mathrm{N}$ treatments, respectively. Soil solution $\mathrm{NH}_{4}-\mathrm{N}$ concentrations were less than 1 $\mathrm{mg} \cdot \mathrm{L}^{-1} \mathrm{~N}$ in most cases, even though $\mathrm{NH}_{4}-\mathrm{N}$ in fertigation solution was between $25 \%$ and $36 \%$ of the total $\mathrm{N}$ applied. This suggests that $\mathrm{N}_{\text {in }} \mathrm{NH}_{4}{ }^{+}$ form was rapidly nitrified. No significant differences $(P>0.05)$ were observed in the amount of soil solution inorganic $\mathrm{N}$ in samples collected before fertigation and after the fertigation events which suggests that inorganic $\mathrm{N}$ is persistent in the soil solution, even days after fertigation (Fig. 2). However, during two fertigations inorganic $\mathrm{N}$ concentrations increased immediately after fertigation.

Table 6. Economic analysis of nitrogen $(\mathrm{N})$ fertilization for tropical pumpkin production in Guánica, PR.

\begin{tabular}{lccc}
\hline $\begin{array}{l}\text { Fertilizer } \mathbf{N} \\
\text { level }\left(\mathbf{k g} \cdot \mathrm{ha}^{-1}\right)^{\mathrm{z}}\end{array}$ & $\begin{array}{c}\text { Fertilizer } \\
\text { cost }(\$ / \mathrm{ha})^{\mathrm{z}}\end{array}$ & $\begin{array}{c}\text { Gross profit } \\
(\$ / \mathrm{ha})\end{array}$ & $\begin{array}{c}\text { Value/cost }(\$ \text { crop/ } \\
\text { \$ fertilizer } \mathbf{N})\end{array}$ \\
\hline 112 & 740 & 10,308 & \\
281 & 1,179 & 15,720 & 12.7 \\
\hline
\end{tabular}

${ }^{\mathrm{z}} 1 \mathrm{~kg} \cdot \mathrm{ha}^{-1}=0.8922 \mathrm{lb} /$ acre$; \$ 1 / \mathrm{ha}=\$ 0.4047 /$ acre.

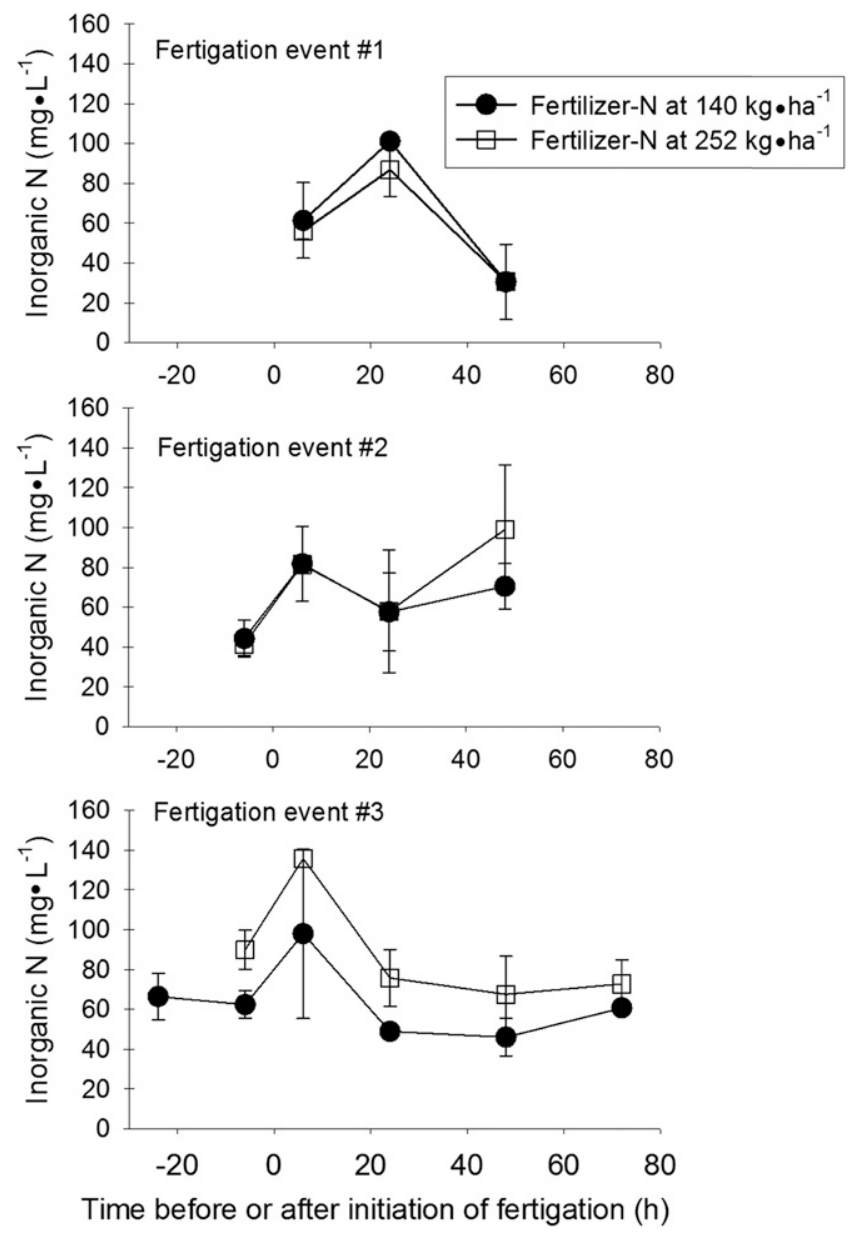

Fig. 2. Soil solution inorganic nitrogen $(\mathrm{N})\left[\operatorname{ammonium} \mathrm{N}\left(\mathrm{NH}_{4}{ }^{+} \mathrm{N}\right)\right.$ plus nitrate $\left.\mathrm{N}\left(\mathrm{NO}_{3}{ }^{-} \mathrm{N}\right)\right]$ in samples collected during $(\approx 5 \mathrm{~h}$ after initiation of irrigation $)$ and after a fertigation event (event 1 ), and before, during and after two other fertigation events (events 2 and 3 ) in onion plots at Guánica, PR, fertigated with low $\left(140 \mathrm{~kg} \cdot \mathrm{ha}^{-1}\right)$ and high $\left(252 \mathrm{~kg} \cdot \mathrm{ha}^{-1}\right)$ fertilizer-N treatments. Values are means \pm SD of two replicates, at each of two depths [ 6 and 12 inches (15.2 and 30.5 $\mathrm{cm})] ; 1 \mathrm{mg} \cdot \mathrm{L}^{-1}=1 \mathrm{ppm}, 1 \mathrm{~kg} \cdot \mathrm{ha}^{-1}=0.8922 \mathrm{lb} /$ acre.

Mean inorganic $\mathrm{N}$ concentrations were 66 and $58 \mathrm{mg} \cdot \mathrm{L}^{-1}$ of $\mathrm{N}$ at $15 \mathrm{~cm}$ and 73 and $61 \mathrm{mg} \cdot \mathrm{L}^{-1}$ of $\mathrm{N}$ at $30 \mathrm{~cm}$ for the 140 and $252 \mathrm{~kg} \cdot \mathrm{ha}^{-1}$ of $\mathrm{N}$, respectively.

\section{Conclusions}

Increasing fertilizer- $\mathrm{N}$ rate beyond $140 \mathrm{~kg} \cdot \mathrm{ha}^{-1}$ of $\mathrm{N}$ did not result in increased onion yield. Fertilizer-N at $280 \mathrm{~kg} \cdot \mathrm{ha}^{-1}$ of $\mathrm{N}$ increased tropical pumpkin yield and economic return. However, at the high fertilizer- $\mathrm{N}$ rate a net loss of $175 \mathrm{~kg} \cdot \mathrm{ha}^{-1}$ of $\mathrm{N}$ from the soil was estimated with $126 \mathrm{~kg} \cdot \mathrm{ha}^{-1}$ of $\mathrm{N}$ remaining in the soil profile below the rooting zone. Although many growers in Puerto Rico fertilize beyond $140 \mathrm{~kg} \cdot \mathrm{ha}^{-1}$ of $\mathrm{N}$ for onion and it may be economically attractive to fertilize over $112 \mathrm{~kg} \cdot \mathrm{ha}^{-1}$ of $\mathrm{N}$ for tropical pumpkin, in similar conditions as in our study, the potential environmental impact may offset potential economic gains. 


\section{Literature cited}

Alers-Alers, S., E. Orengo, and L. Cruz Perez. 1979. Influence of various N-P-K fertilizer levels on onion production in southern Puerto Rico. J. Agr. Univ. P R. 63:111-115.

Colberg, O. and A. Beale. 1991. Cuatro niveles de nitrógeno en dos variedades de cebolla (Allium cepa). J. Agr. Univ. P R. 75:1-9.

Di Rienzo, J.A., F. Casanoves, M.G. Balzarini, L. Gonzalez, M. Tablada, and C.W. Robledo. 2014. InfoStat. National University of Córdoba, Córdoba, Argentina. 7 Oct. 2016. <http://infostat.com. ar $/>$.

Drost, D. and R. Koeing. 2002. Nitrogen use efficiency and onion yield increased with a polymer-coated nitrogen source. HortScience 37:338-342.

Ells, J.E., A.E. McSay, P.N. Soltanpour, F.C. Schweissing, M.E. Bartolo, and E.G. Kruse. 1993. Onion irrigation and nitrogen leaching in the Arkansas Valley of Colorado 1990-1991. HortTechnology 3:184-187.

Halvorson, A.D., R.F. Follet, M.E. Bartolo, and F.C. Schweissing. 2002. Nitrogen fertilizer use efficiency of furrow-irrigated onion and corn. Agron. J. 94:442-449.
Halvorson, A.D., M.E. Bartolo, C.A Reule, and A. Berrada. 2008. Nitrogen effects on onion yield under drip and furrow irrigation. Agron. J. 100:10621069.

Harrelson, E.R., G.D. Hoyt, J.L. Havlin, and D.W. Monks. 2008. Effect of planting date and nitrogen fertilization rates on no-till pumpkins. HortScience 43:857861.

Puerto Rico Department of Agriculture. 2011. Compendio estadístico 2010. Puerto Rico Dept. Agr., Stat. Div., San Juan, PR.

Olson, S.M., W.M. Stall, N.A. Peres, and S.E. Webb. 2011. Onion, leek, and chive production in Florida, p. 167-179. In: S.M. Olson and B. Santos (eds.). Vegetable production handbook for Florida. Univ. Florida, Inst. Food Agr. Sci., Gainesville, FL.

Rodríguez, J.M. 2006. Evaluation of hydrologic conditions and nitrate concentrations in the Río Nigua de Salinas Alluvial Fan Aquifer, Salinas. U.S. Dept. Interior, U.S. Geological Survey, Sci. Investigations Rpt. 2006-5062.

Shock, C.C., J.K. Ishida, E.P. Eldredge, and M. Seddigh. 2000. Yield of yellow onion cultivars in eastern Oregon and southwestern Idaho. HortTechnology 10:613-620.
Swiader, J.M. and W.H. Shoemaker. 2004. Rotational cropping sequence affects nitrogen fertilizer requirements in processing pumpkins (Cucurbita moschata). HortScience 39:75-79.

University of Puerto Rico, Agricultural Experiment Station. 2012a. Conjunto tecnológico para la producción de cebolla. Univ. Puerto Rico, Agr. Expt. Sta., Publ. 156.

University of Puerto Rico, Agricultural Experiment Station. 2012b. Conjunto tecnológico para la producción de calabaza. Univ. Puerto Rico, Agr. Expt. Sta., Publ. 155.

U.S. Department of Agriculture. 2008. Soil survey of San Germán area, Puerto Rico. U.S. Dept. Agr., Natural Resources Conservation Serv., Ser. 2008.

Wessel-Beaver, L. 2005. Release of 'Soler' tropical pumpkin. J. Agr. Univ. P R. 89:263-266.

Witt, C., J.M.C.A. Pasuquin, R. Mutters, and R.J. Buresh. 2005. New leaf color chart for effective nitrogen management in rice. Better Crops Plant Food 89:36-39.

Wyenandt, C.A., J.R. Heckman, and N.L. Maxwell. 2008. Pumpkin fruit size and quality improve with leaf mulch. HortTechnology 18:361-364. 